\title{
Effects of temperature and oxygen tension on oxygen consumption rates of nauplii of different Artemia strains
}

\author{
I. Varó ${ }^{1}$, A. C. Taylor ${ }^{2}$, J. C. Navarro ${ }^{3}$, F. Amat $^{1}$ \\ 'Instituto de Acuicultura de Torre de la Sal (C.S.I.C), E-12695 Ribera de Cabanes, Castellón, Spain \\ ${ }^{2}$ Department of Zoology, University of Glasgow, Glasgow G12 8QQ, Scotland, United Kingdom \\ ${ }^{3}$ NERC Unit of Aquatic Biochemistry, Department of Molecular and Biological Sciences, University of Stirling, Stirling FK9 \\ 4LA, Scotland, United Kingdom
}

\begin{abstract}
Effects of temperature and $\mathrm{PO}_{2}$ have been examined on rates of oxygen consumption $\left(\mathrm{Mo}_{2}\right)$ of nauplii of 5 differents Artemia strains acclimated to $30 \% \mathrm{~S}$. In 4 strains there were no significant differences in relations between $\mathrm{Mo}_{2}$ and temperature over the temperature ranges offered $\left(15\right.$ to $\left.35^{\circ} \mathrm{C}\right)$. In 1 strain (Delta del Ebro), the temperature effect on $\mathrm{MO}_{2}$ was much lower than in the other strains. Nauplii of all strains were able to maintain respiratory independence under hypoxic conditions down to a Pc of 30 to 40 Torr $\left(15\right.$ to $\left.20^{\circ} \mathrm{C}\right)$. The ability of the nauplii to maintain respiratory independence was reduced at higher temperatures. Nauplii from each of the strains were able to tolerate temperatures of up to $35^{\circ} \mathrm{C}$; at high temperatures $Q_{10}$ values for $\mathrm{MO}_{2}$ for 3 strains decreased; this may indicate that these nauplii were thermally stressed. Differences in temperature effects on metabolic rates of nauplii of the 5 strains are discussed in relation to the competitive abilities of the strains in their natural habitat.
\end{abstract}

\section{INTRODUCTION}

The brine shrimp Artemia inhabits isolated inland saline ponds, lakes and coastal salterns. Substantial differences in water temperature and salinity have been recorded for many of these habitats which may also show quite large diel and seasonal fluctuations in oxygen concentrations (e.g. Bowen et al. 1978, Persoone \& Sorgeloos 1980, Browne \& Macdonald 1982, Vanhaecke et al. 1987).

Variations in temperature may cause pronounced changes in Artemia populations. Temperature influences on population performance can be used to examine variations between geographic and taxonomic strains of Artemia under laboratory and/or field conditions. Differences in the responses of different Artemia strains to temperature can be important in explaining changes in Artemia populations when different strains co-exist in a given habitat and competitive-exclusion mechanisms may be operating (Browne 1980, Amat 1983). Exclusion of one strain due to competitive interaction between populations over short periods of time could be explained by different genotypic (Abreu-Grobois \& Beardmore 1980, Gajardo $\&$ Beardmore 1989) and phenotypic adaptations among species, and within populations of the same species (Browne et al. 1984, Browne \& Halanych 1989).

Few studies have been carried out on metabolic characteristics of larvae of different Artemia strains. Influences of temperature on oxygen consumption of nauplii has been studied in several Artemia strains; however the results of these investigations are contradictory. While some authors demonstrated an increase in oxygen consumption with increased temperature (e.g. Engel \& Angelovic 1969), differences in temperature tolerance have been reported between bisexual and parthenogenetic Artemia strains (Amat 1983, Vanhaecke et al. 1984).

Several Artemia strains have been identified by Abreu-Grobois \& Beardmore (1980), and it might be expected that some strains are better adapted to withstand changes in environmental conditions than others. The present study investigates the effect of temperature and oxygen tension on oxygen consumption of 4 different strains of Artemia nauplii from Spain, and 1 strain from North America, acclimated to $30 \% \mathrm{~S}$. The latter was included because it has been suggested that European bisexual strains may be less tolerant of high temperature than American bisexual ones (Vanhaecke et al. 1984). 


\section{MATERIAL AND METHODS}

Experimental animals. Dried Artemia cysts from the following populations were used:

(1) Delta del Ebro, NE Spain (year of harvest 1984); parthenogenetic tetraploid (PT).

(2) La Mata, E Spain (1987); parthenogenetic diploid (PD).

(3) Janubio, Lanzarote, Canary Islands, Spain (1988); parthenogenetic diploid (PD).

(4) Cádiz, SW Spain (1987); bisexual (B)

(5) Great Salt Lake, Utah, USA (supplied by ATP 1990, Type AT-3, lot AO190); bisexual (B).

Artificial sea water (Tropic Marine) of $30 \% \mathrm{~S}$ was used in all experiments. No effects of salinity on rates of oxygen consumption of Artemia have been reported (Kinne 1964). All nauplii were hatched at $28^{\circ} \mathrm{C}$ under conditions of continuous illumination and aeration. After hatching, nauplii were separated from their shells and remaining unhatched cysts discarded (Amat 1985). Nauplii were then washed thoroughly in sea water and transferred to clean filtered sea water $(0.2 \mu \mathrm{m}$, Whatman WCN/filters) with a very low bacterial content, and acclimated to $20^{\circ} \mathrm{C} \pm 0.5 \mathrm{C}^{\circ}$ under constant aeration and illumination for $24 \mathrm{~h}$ in an incubator. Nauplii were then washed again, transferred to clean filtered sea water and exposed to experimental temperatures for $30 \mathrm{~min}$ during which time the water was aerated. The filtered sea water had a very low level of bacterial contamination, therefore washing the nauplii upon each transfer to a new medium ensured that the number of bacteria transferred with the nauplii was kept to a minimum. This was particularly important in the respirometry experiments to keep microbial respiration as low as possible.

Measurements of oxygen consumption. Rates of oxygen consumption were determined using a closed micro-respirometer ( $\mathrm{RC}-300$ respiration cell, Strathkelvin Instruments, Glasgow, UK). Two micro-respirometers were connected in series with a constant-temperature water bath. A micro-cathode oxygen electrode (Instrumentation Laboratories) was inserted into the micro-respirometer and connected to an oxygen meter (Model 781. Strathkelvin Instruments) which was in turn connected to a chart recorder.

The oxygen electrodes were calibrated before each experiment using a solution of sodium sulphite and $0.01 \mathrm{M}$ sodium tetraborate $\left(\mathrm{PO}_{2}=0\right.$ Torr $)$, and $1 \mathrm{ml}$ of aerated, filtered sea water at the experimental temperature. The water in the respirometer was not stirred, because the rate of oxygen consumption by the electrode is extremely low $\left(3.25 \times 10^{-6} \mathrm{umol} \mathrm{O}_{2} \mathrm{~h}^{-1}\right)$ due to the small surface area of the cathode and did not cause significant local depletion of oxygen near the electrode More importantly, stirring also affected the behaviour of the nauplii in the respirometer and observations showed that the swimming movements of nauplii kept the water in the chamber well mixed

After calibration, a $1 \mathrm{ml}$ suspension of nauplii was placed into the respirometer chambers. The number of nauplii added varied between 100 and 500; in most of the experiments between 150 and 300 nauplii were used. Preliminary experiments showed that within this range oxygen consumption rates of individual nauplii were not affected by the density of nauplii within the chamber. Each experimental run continued until the $\mathrm{PO}_{2}$ had declined to less than 10 Torr. Each run lasted between $45 \mathrm{~min}$ and $3 \mathrm{~h}$ depending on the temperature and the number of individuals used. The nauplii were then removed from the micro-respirometer chambers for counting. Control experiments in which no nauplii were present in the chambers were run at the end of each experiment to enable the rate of 'background respiration of the water in the chambers to be determined. After each experiment, chambers and electrodes were soaked in a dilute solution of benzalkonium chloride $(0.1 \%)$ then rinsed thoroughly with distilled water to reduce microbial growth within the chamber.

Rates of oxygen consumption were determined at the acclimation temperature of $20^{\circ} \mathrm{C}$ and after exposure to $15,25,30$ or $35^{\circ} \mathrm{C}$. Rates of oxygen consumption were calculated from chart traces at $\mathrm{Po}_{2}$ intervals of 10 Torr after subtraction of the mean rate of oxygen consumption of the water obtained from control runs.

To determine the weight-specific rate of oxygen consumption $\left(\mathrm{MO}_{2}\right)$, nauplii of each strain were weighed and their total length measured every $2 \mathrm{~h}$ for a $6 \mathrm{~h}$ period, to ensure that no significant growth took place during the recordings. Batches of 100 nauplii were dried in an oven at $65^{\circ} \mathrm{C}$ for $24 \mathrm{~h}$ and weighed to the nearest $0.0001 \mathrm{mg}$ on a Sartorius Supermicro Balance; then the average weight of nauplius was calculated.

Weight-specific rates of oxygen consumption $\left(\mathrm{MO}_{2}\right)$ under nomoxic conditions were calculated from the parts of the chart traces which indicated that the $\mathrm{PO}_{2}$ of the water in the respirometer had not decreased below 100 Torr. This procedure ensured that the rates calculated were those of individuals under normoxic conditions and that they were not affected by hypoxia. $Q_{10}$ values were calculated from the $\mathrm{Mo}_{2}$ values over the range of temperatures tested using the Van't Hoff equation (Schmidt-Nielsen 1990).

\section{RESULTS}

Naupliar size (um) was measured to assess whether significant growth took place during the experimental time. The variation in size of different Artemia nauplii 
Table 1 Artemia. Variation in size of different nauplii strains between 24 and $30 \mathrm{~h}$ of acclimation to experimental conditions. Values are means $\pm S D$; number of obvervations $=100$ Values with the same letter within a strain are not significantly different (Tukey test, $\mathrm{p} \leq 0.05$ )

\begin{tabular}{|lcl|}
\hline Strain & Age of naupli $(\mathrm{h})$ & \multicolumn{1}{c|}{ Size $(\mathrm{um})$} \\
\hline Delta del Ebro & 24 & $722.50 \pm 43.15 \mathrm{a}$ \\
& 26 & $723.75 \pm 45.83 \mathrm{a}$ \\
& 28 & $735.00 \pm 51.00 \mathrm{a} \mathrm{b}$ \\
La Mata & 30 & $748.50 \pm 57.61 \quad \mathrm{~b}$ \\
& 24 & $658.50 \pm 51.02 \mathrm{a}$ \\
& 26 & $672.25 \pm 42.12 \mathrm{a} \mathrm{b}$ \\
Janubio & 28 & $668.00 \pm 45.97 \mathrm{a} \mathrm{b}$ \\
& 30 & $679.75 \pm 42.97 \quad \mathrm{~b}$ \\
& 24 & $660.59 \pm 34.30 \mathrm{a}$ \\
Cádiz & 26 & $663.75 \pm 32.50 \mathrm{a}$ \\
& 28 & $667.00 \pm 29.92 \mathrm{a}$ \\
& 30 & $684.00 \pm 24.27 \quad \mathrm{~b}$ \\
& 24 & $704.50 \pm 56.45 \mathrm{a}$ \\
Great Salt Lake & 26 & $699.25 \pm 61.59 \mathrm{a}$ \\
& 28 & $705.25 \pm 61.16 \mathrm{a}$ \\
& 30 & $716.00 \pm 56.13 \mathrm{a}$ \\
& 24 & $763.00 \pm 35.08 \mathrm{a}$ \\
& 26 & $755.50 \pm 43.17 \mathrm{a}$ \\
& 28 & $759.50 \pm 31.94 \mathrm{a}$ \\
& 30 & $762.75 \pm 41.21 \mathrm{a}$ \\
\hline
\end{tabular}

strains between 24 and $30 \mathrm{~h}$ of acclimation to the experimental conditions is given in Table 1 . There were significant differences in size for nauplii of parthenogenetic strains during the period from 24 to $30 \mathrm{~h}$ ( $\mathrm{p} \leq 0.05$, ANOVA; Sokal \& Rohlf 1981). However, a Tukey multiple range test, a posteriori, (Sokal \& Rohlf 1981) showed that differences in naupliar size became significant $(p \leq 0.05)$ only after $28 \mathrm{~h}$. In bisexual strains, there were no significant differences ( $p \geq 0.05$, ANOVA) in naupliar size within the same period of acclimation. Thus, no significant growth took place during the time in which measurements of oxygen consumption were carried out, since the maximum duration of each experiment was always less than $4 \mathrm{~h}$.

Fig. 1 shows the effect of temperature on the relationship between weight-specific rate of oxygen consumption $\left(\mathrm{MO}_{2}\right)$ for the different strains and oxygen tension $\left(\mathrm{PO}_{2}\right)$. Nauplii from all strains were able to maintain their $\mathrm{Mo}_{2}$ approximately constant over a wide range of ambient $\mathrm{PO}_{2}$. The value for the 'critical $\mathrm{Po}_{2}$ ' $(\mathrm{PC})-$ the $\mathrm{Po}_{2}$ at which respiratory independence could no longer be maintained - was dependent on temperature; an increase in temperature resulted in a small increase in PC. Between 15 and $20^{\circ} \mathrm{C}$, Pc was in the range 30 to 40 Torr. At higher temperatures, however, Pc increased between 40 and 60 Torr. At lower oxygen tensions, $\mathrm{Mo}_{2}$ declined rapidly and the nauplii began to swim together near the bottom of the chamber. At very low oxygen tensions $\left(\mathrm{PO}_{2}=5\right.$ to 10 Torr) the nauplii became quiescent, but soon recovered when transferred to aerated sea water.

Values for $\mathrm{MO}_{2}$ of each strain at each temperature tested are presented in Fig. 2. All strains showed a linear relationship between $\mathrm{Mo}_{2}$ and temperature. The regression equations of these lines are given in Table 2 Covariance analysis (Sokal \& Rohlf 1981) showed that the regression coefficients (slopes) were significantly different $(p \leq 0.05)$. Further analysis indicated that the regression coefficient for the Delta del Ebro strain was significantly different from those of the other 4 strains, which did not differ significantly $(p \leq 0.05)$. These differences were checked by means of the Tukey test, and the results given in Table 2. $Q_{10}$ values calculated over $5^{\circ} \mathrm{C}$ intervals using the Van't Hoff equation are presented in Table 3. In all strains, a significant effect of temperature on $\mathrm{Q}_{10}$ was observed.

\section{DISCUSSION}

Comparisons of metabolic rates among ectothermic animals are usually made using data on the 'standard' rate of metabolism. During the present study, attempts were made to record oxygen consumption rates of inactive specimens, but this proved impossible since, except under conditions of severe hypoxia, the nauplii of all the strains were observed to swim continuously. The rates recorded were therefore probably more representative of the 'routine' rate of oxygen consumption than the 'standard' rate in these animals.

It is now well established that the metabolic rate of invertebrates varies with size (e.g. Vernberg 1983, Schmidt-Nielsen 1990). During the present study attempts were therefore made to ensure that all recordings were carried out using individuals of very similar size. Thus, the nauplii used were always between 24 and $28 \mathrm{~h}$ old since, during this period, no significant growth was observed among any of the strains (see Table 1).

The nauplii of all of the different Artemia strains showed a considerable degree of respiratory independence since they were able to maintain their oxygen consumption rates approximately constant over a wide range of $\mathrm{PO}_{2}$. $\mathrm{PC}$ values were very similar among the strains. The PC values of all the strains increased with increasing temperature. This increase indicates that the ability of the nauplii to maintain respiratory independence during hypoxia decreases with higher temperatures. This effect has been recorded previously for many marine invertebrates (Herreid 1980) and appears to be due to difficulty in sustaining oxygen uptake at the respiratory surfaces under low oxygen tension.

Artemia adults have been shown to maintain a con- 

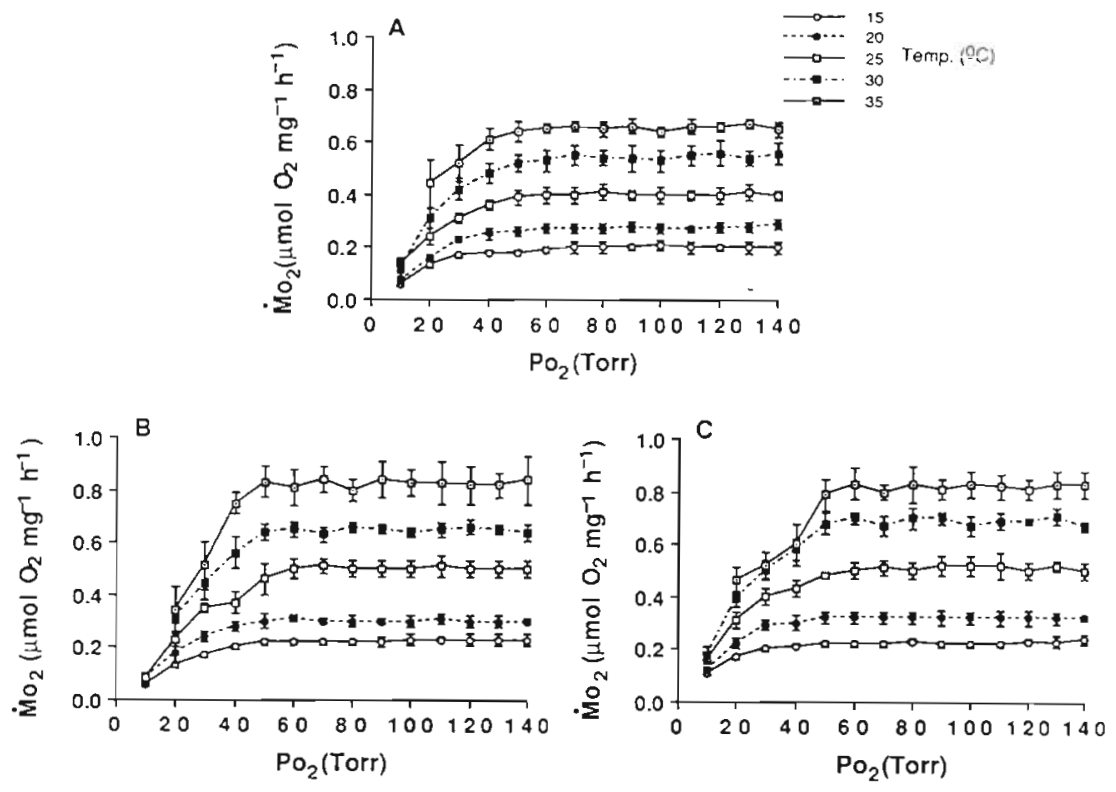
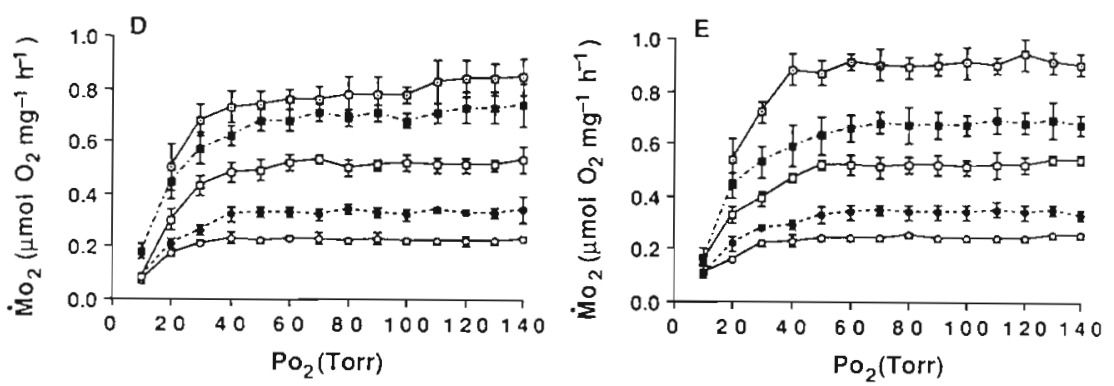

Fig. 1. Artemia. Effect of temperature on the relationship between the oxygen consumption rate $\left(\mathrm{MO}_{2}\right)$ and the partial pressure of oxygen $\left(\mathrm{PO}_{2}\right)$ for nauplii from (A) Delta del Ebro, (B) La Mata, (C) Janubio, (D) Cádiz and (E) Great Salt Lake strains. Values are means $\pm \mathrm{SD}$ stant oxygen consumption rate above the critical oxygen concentration of $\mathrm{ca} 2 \mathrm{ml} \mathrm{l}^{-1}\left(\mathrm{PO}_{2} \approx 65\right.$ Torr $)$, although this value can decrease with long-term accli-

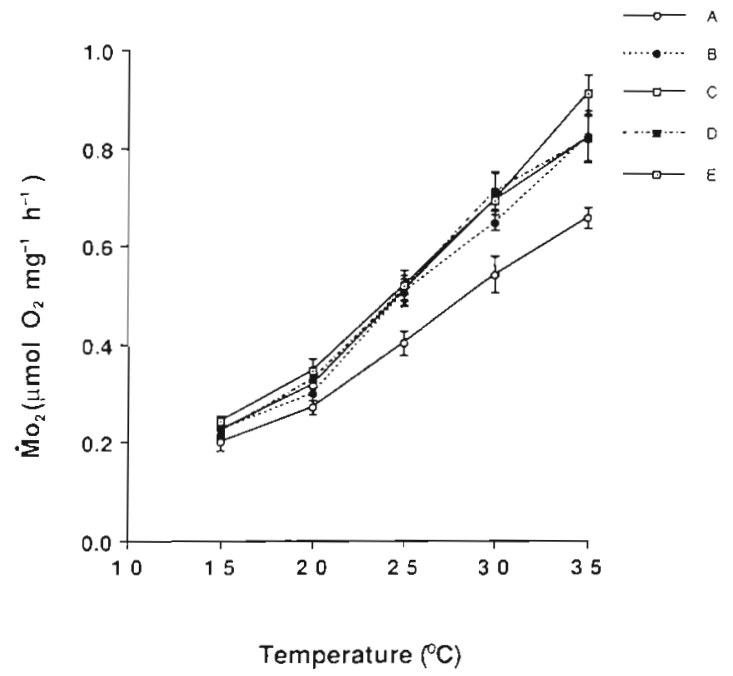

Fig. 2. Artemia. Relationship between oxygen consumption rate $\left(\mathrm{MO}_{2}\right)$ and temperature for nauplii from the Delta del Ebro (A), La Mata (B), Janubio (S), Cádiz (D) and Great Salt Lake (E) strains. Values are means $\pm \mathrm{SD}$ mation to hypoxic conditions (Vos et al. 1979, Decleir et al. 1980). It has been suggested that this increase in the ability to maintain respiratory independence during hypoxia may be due to the synthesis of a new haemoglobin (Hb III). Van den Branden et al. (1978) reported that the 3 haemoglobins present in adult Artemia (Hb I, II and III) are adapted to function efficiently at different levels of oxygen availability. Hb I being more efficient in oxygen-rich water, and $\mathrm{Hb}$ III being most efficient when the $\mathrm{PO}_{2}$ of the water is very low. As far as we are aware, the effect of oxygen tension on the respiration rate of Artemia nauplii has not previously been investigated. Heip et al. (1977) showed that the first haemoglobin present in free-swimming nauplii was $\mathrm{Hb}$ II. $\mathrm{Hb}$ If was present in the nauplii from $4 \mathrm{~h}$ after hatching and within $24 \mathrm{~h} \mathrm{Hb}$ III was also present. Since all nauplii used in the present experiments were $24 \mathrm{~h}$ old, the presence of these haemoglobins, especially Hb III which has been shown to have a lower temperature sensitivity, could be important in enabling the nauplii to maintain their oxygen consumption rates under hypoxic conditions.

Not all marine invertebrates which regulate their oxygen consumption rates under declining oxygen ten- 
Table 2. Artemia. Regression equations describing the relationship between routine $\mathrm{Mo}_{2}\left(y=\mu \mathrm{mol} \mathrm{O}_{2} \mathrm{mg}^{-1} \mathrm{~h}^{-1}\right)$ and temperature $\left(T ;{ }^{\circ} \mathrm{C}\right)$ for nauplii of different strains, and results of Tukey test after covariance analysis (for further explanation see text). Strains with different letters show significant differences $(\mathrm{p} \leq 0.05)$ after Tukey test. The Tukey test was not able to determine that Cádiz strain was significantly from either the Janubio or La Mata strain; this is shown in the form of overlapping sets of similarities (i.e. at least one Type II error has been committed, Zar 1984). n: no. of observations

\begin{tabular}{|c|c|c|c|c|c|}
\hline Strain & & Regression equation & $r$ & Sig. level & $\mathrm{n}$ \\
\hline Delta del Ebro & $\cdots$ & $y=-0.187+0.0240 I$ & 0.99 & 0.0000 & 38 \\
\hline La Mata & $\mathrm{a}$ & $y=-0.279+0.0311 T$ & 0.98 & 0.0000 & 38 \\
\hline Janubio & $\mathrm{b}$ & $y=-0.267+0.0312 T$ & 0.99 & 0.0000 & 33 \\
\hline Cádiz & $a b$ & $y=-0.272+0.0317 T$ & 0.99 & 0.0000 & 38 \\
\hline Great Salt Lake & c & $y=-0.294+0.0335 T$ & 0.98 & 0.0000 & 37 \\
\hline
\end{tabular}

sion have an active compensatory mechanism (see review by Herreid 1980). Diffusion of oxygen from the surrounding water to the tissues may be more efficient in small animals with a relatively high surface area to volume ratio, and this might be the case for Artemia nauplii given that they lack any specialized respiratory system. This may also be true for Euphausia superba larvae since Quetin \& Ross (1989) have shown that the Pc value was lower in the newly hatched larvae than in the embryo. These authors attributed the increase in respiratory independence of the larvae to an increase in their surface area to volume ratio.

Artemia nauplii may therefore use a combination of both active and passive mechanisms to enable them to maintain their oxygen consumption rates constant over a range of oxygen tensions. This regulatory capacity enables the nauplii to cope with the fluctuations in oxygen tension to which they appear to be regularly exposed in their natural habitats. During this study it was noted that when the $\mathrm{PO}_{2}$ of the water declined to very low levels $\left(\mathrm{PO}_{2}<5\right.$ to 10 Torr) the nauplii stopped swimming and became quiescent at the bottom of the respirometer chamber. The majority of the nauplii could, however, survive brief $(30 \mathrm{~min})$ exposure to such severe hypoxia, since they soon recovered once the $\mathrm{PO}_{2}$ of the water was increased to normoxic levels. The ability to tolerate such conditions decreased at higher temperatures.

Table 3. Artemia. $\mathrm{Q}_{10}$ values over $5^{\circ} \mathrm{C}$ intervals for $\mathrm{MO}_{2}$ of nauplii of different strains

\begin{tabular}{|c|c|c|c|c|}
\hline \multirow[t]{2}{*}{ Strain } & \multicolumn{4}{|c|}{ Temperature interval } \\
\hline & $15-20^{\circ} \mathrm{C}$ & $20-25^{\circ} \mathrm{C}$ & $25-30^{\circ} \mathrm{C}$ & $30-35^{\circ} \mathrm{C}$ \\
\hline Delta del Ebro & 1.84 & 2.20 & 1.82 & 1.47 \\
\hline La Mata & 1.78 & 2.78 & 1.65 & 1.62 \\
\hline Janubio & 1.99 & 2.56 & 1.84 & 1.40 \\
\hline Cádiz & 2.21 & 2.42 & 1.93 & 1.32 \\
\hline Great Salt Lake & 2.02 & 2.25 & 1.76 & 1.74 \\
\hline
\end{tabular}

As in other ectothermic animals, the 'routine' weightspecific rates of oxygen consumption $\left(\mathrm{MO}_{2}\right)$ of different strains of Artemia nauplii were affected by temperature. It was found that, throughout the whole temperature range, nauplii of the Delta del Ebro strain had much lower rates of oxygen consumption than the other strains ( $p \leq 0.05$, ANOVA). In addition, the effect of temperature on the $\dot{M}_{2}$ of the Delta del Ebro strain was lower than that observed for the other strains. Small, but significant, differences in $\mathrm{Mo}_{2}$ at each of the experimental temperatures were found among these 4 strains (see Fig. 2). Thus, at all temperatures, nauplii of the Great Salt Lake strain had the highest $\mathrm{Mo}_{2}$ and those of the La Mata strain the lowest. No clear differences were found, however, between the $\mathrm{Mo}_{2}$ values for the Cádiz, La Mata and Janubio strains.

Engel \& Angelovic (1968), working with 1 d old Artemia nauplii from Great Salt Lake, also found that $\mathrm{MO}_{2}$ increased with an increase in temperature from 10 to $30^{\circ} \mathrm{C}$. Present results show that during short-term exposure to acute changes in temperature all the Artemia strains were able to cope with a range from 15 to $35^{\circ} \mathrm{C}$. The differences in the oxygen consumption rates between tetraploid and diploid strains (asexual and sexual) could be the result of genetic differentiation between Artemia species (Abreu-Grobois \& Beardmore 1980). Further, the lower effect of temperature on $\mathrm{MO}_{2}$ in the Delta del Ebro (tetraploid) strain than in the other strains could be interpreted as indicating that this strain is better adapted to a wide range of temperature.

Nauplii in this study were able to tolerate temperatures of up to $35^{\circ} \mathrm{C}$. However, in some strains, $Q_{10}$ decreased at the highest experimental temperatures. This may indicate that the nauplii were stressed, since they were unable to maintain the same increase in $\mathrm{MO}_{2}$ at these high temperatures. A similar reduction in $\mathrm{Q}_{10}$ at higher temperatures has been recorded in some other invertebrates (Widdows 1973, Shirley et al. 1978, Zainal 1990).

Engel \& Angelovic (1968) found that nauplii from 
Great Salt Lake could tolerate temperatures of up to $30^{\circ} \mathrm{C}$ and had a lower lethal temperature limit of between 5 to $8^{\circ} \mathrm{C}$. Vanhaecke et al. (1984) reported on the effects of various salinity-temperature combinations (range 18 to $34^{\circ} \mathrm{C}$ ) on the survival of nauplii of 13 Artemia strains. They found that most strains had a high tolerance to low temperatures but, at high temperatures (between 30 and $34^{\circ} \mathrm{C}$ ), European bisexual strains were less tolerant (with high mortalities at $30^{\circ} \mathrm{C}$ ) than parthenogenetic strains, while the Great Salt Lake strain was the most tolerant of high temperature. This is perhaps not surprising since seasonal changes in temperature between 0 and $40^{\circ} \mathrm{C}$ have been recorded in Great Salt Lake (Stephens \& Gillespie 1972).

In contrast to Vanhaecke et al. (1984), it was shown during the present study that the European bisexual strains can tolerate acute exposure to temperatures of $35^{\circ} \mathrm{C}$. This could be explained by differences in the thermal history of the experimental specimens, since a high temperature, tolerated over a short exposure, may eventually become lethal (Cossins \& Bowler 1987). An alternative explanation might be that Vanhaecke et al. (1984) used larvae of up to $9 \mathrm{~d}$ old, which may differ physiologically from the $1 \mathrm{~d}$ old nauplii used in this study, $Q_{10}$ values for the $\dot{M o}_{2}$ of the Great Salt Lake and La Mata nauplii remained relatively constant throughout the temperature range 15 to $35^{\circ} \mathrm{C}$, which suggests that they may be well adapted to withstand temperature fluctuations within this range.

Temperature had a significant effect on oxygen consumption rates but, in the tetraploid strain, this effect was less pronounced than in the diploid strains studied. This agrees with previous reports which indicate that polyploid populations are better adapted genetically than diploid animals to surviving exposure to extreme environmental conditions (Artom 1931, Chapman 1968, Metalli \& Ballardin 1972). Results obtained in recent field and laboratory research carried out by our group further support this generality. These results reveal that in wild and laboratory populations of Artemia, diploid strains always show similar behavior to their tetraploid counterparts. This seems to be particularly true for changes in reproductive patterns related to changes in temperature.

On some Spanish salterns there is a seasonal occurrence of bisexual and parthenogenetic strains. The former dominates in winter and spring, whereas during summer and early autumn the Artemia population consists almost entirely of parthenogenetic individuals (Amat 1983), especially the tetraploid form in conditions of extreme temperature. It has been suggested that this seasonal variation in the composition of the population might be due to differences in the temperature tolerance of bisexual and parthenogenetic strains (Amat 1983). During the present study, however, no significant differences in effect of temperature on $\mathrm{Mo}_{2}$ were observed between the bisexual and parthenogenetic diploid strains. These experiments were carried out on nauplii acclimated to $30 \% \mathrm{~S}$ and further information is needed to establish whether temperature tolerance can be affected by salinity.

Acknowledgements. We thank Prof. R. S. Phillips for providing research facilities at the Department of Zoology. University of Glasgow. I. Varó was supported by Caja Insular de Ahorros de Canarias and Generalitat Valenciana and J.C. Navarro was supported by Programa Nacional de Becas de Formación de Personal Investigador en el Extranjero (Subprograma de Perfeccionamiento para Doctores y Técnologos).

\section{LITERATURE CITED}

Abreu-Grobois, F. A., Beardmore, J. A. (1980). International study on Artemia. II. Genetic characterization of Artemia populations - an electrophoretic approach. In: Persoone, G. et al. (eds.) The brine shrimp Artemia, Vol. 1, Morphology, genetics, radiobiology, toxicology. Universal Press, Wetteren, Belgium, p. 133-146

Amat, F. (1983). Zygogenetical and parthenogenetical Artemia in the Cádiz sea side salterns. Mar. Ecol. Prog. Ser 13: 291-293

Amat, F. (1985). Utilización de Artemia en acuicultura. Inf. Técn. Inst. Inv. Pesq. 128-129: 60

Artom, C. (1931). L'origine e l'evoluzione della paretenogenesi attraverso i differenti biotipi di una specie collectiva (Artema salina L.) con special riferimento al biotipo diploid partenogenetico di Sete. Memorie R. Accad. Ital. 2: $1-57$

Bowen, S. T., Durkin, J. P., Sterling, G., Clarck, L. S. (1978). Artemia haemoglobins: genetic variation in parthenogenetic and zygogenetic populations. Biol. Bull. mar biol. Lab., Woods Hole. 155: 273-287

Browne, R. A. (1980). Competition experiments between parthenogenetic and sexual strains of brine shrimp, Artemia salina. Ecology 61. 471-474

Browne, R. A., Macdonald, G. H. (1982). Biogeography of the brine shrimp. Artemia: distribution of parthenogenetic and sexual populations. J. Biogeogr. 9: 331-338

Browne, R. A., Saelle, S. E., Grosh, D. S., Segreti, W. O., Purser S. M. (1984). Partitioning genetic and environmental components of reproduction and lifespan in Artemia. Ecology 65: 949-960

Browne, R. A., Halanych, K. M. (1989). Competition between sexual and parthenogenetic Artemia: a re-evaluation. Crustaceana $57(1): 57-71$

Chapman, J. (1968). The relative adaptive values of parthenogenesis and zygogenesis. M. Sc. thesis, San Francisco State College, California

Cossins, A. R., Bowler, K. (1987). Temperature biology of animals. Chapman and Hail, London, New York

Decleir, W., Vos, J., Bernaerts, F., Van Den Branden, C. (1980). The respiratory physiology of Artemia. In: Persoone, G. et al. (eds.) The bnne shrimp Artemia, Vol. 2, Physiology, biochemistry, molecular biology. Universal Press, Wetteren, Belgium, p. 137-145

Engel, D. W., Angelovic, J. W. (1968). The influence of salinity and temperature upon the respiration of brine shrimp nauplii. Comp. Biochem. Physiol. 26: 749-752

Gajardo, G., Beardmore, J. A. (1989). Ability to switch repro- 
ductive mode in Artemia is related to maternal heterozygosity. Mar Ecol. Prog Ser. 55: 191-195

Heip, J., Moens, L., Kondo, M. (1977). Ontogeny of haemoglobins in the brine shrimp. Artemia salina (L.). Archs int. Physiol. Biochim. 85: 177-178

Herreid, C. F. (1980). Hypoxia in invertebrates. Comp Biochem. Physiol. 67. 311-320

Kinne, $\mathrm{O}$. (1964). The effects of temperature and salinity on marine and brackish water animals. II. Salinity and temperature-salinity combinations. Oceanogr. mar Biol. A. Rev. 2: 281-339

Metalli, P., Ballardin, E. (1972). Radiobiology of Artemia: radiation effects and ploidy. Curr Top. Radiat. Res. Q. 7 $181-240$

Persoone, G. Sorgeloos, P. (1980). General aspects of the ecology and biogeography of Artemia. In: Persoone, G. et al. (eds.) The brine shrimp Artemia, Vol. 3, Ecology, culturing, use in aquaculture. Universal Press, Wetteren, Belgium, p. 3-24

Quetin, L. B., Ross R. M. (1989). Effects of oxygen, temperature and age on the metabolic rate of embryos and early stages of the Antartic krill Euphasia superba Dana. J. exp. mar. Biol. Ecol. 125: 43-62

Schmidt-Nielsen, K. (1990). Animal physiology: adaptation and environment, 4th edn. Cambridge University Press. Cambridge

Shirley, T. C., Denoux, G. J., Stickle, W. B. (1978). Seasonal respiration in the marsh periwinkle, Littorina irrorata. Biol. Bull. mar. biol. Lab., Woods Hole 154: 322-334

Sokal, R. R., Rohlf, F. J. (1981). Biometry. The principles and practice of statistics in biological research, 2nd edn. W H Freeman and Co., San Francisco

Stephens, D. W., Gillespies, D. M. (1972). Community struc-

This article was submitted to the editor ture and ecosystem analysis of the Great Salt Lake. In: Riley, J. P. (ed.) The Great Salt Lake and Utah's water resources. Utah Water Res. Lab., Utah, State University, p. $66-72$

Van Den Branden, C., D'Hondt, J., Moens, L., Decleir, W. (1978). Functional properties of the haemoglobins of Artemia salina L. Comp. Biochem. Physiol. 60: 185-187

Vanhaecke, P., Siddal, S. E., Sorgeloos, P. (1984). International study on Artemia. XXXII. Combined effects of temperature and salinity on the survival of Artemia of various geographical origin. J. exp. mar Biol. Ecol. 80: $259-275$

Vanhaecke, P., Tackaert, W., Sorgeloos, P. (1987). The biogeography of Artemia: an update review. In: Decleir, W. et al. (eds.) Artemia research and its applications, Vol. 1, Morphology, genetic, radiobiology, toxicology, Universal Press, Wetteren, Belgium, p. 129-155

Vernberg, F. J. (1983). Respiratory adaptation. In: Vernberg, J F., Vernberg, W. B. (eds.) The biology of Crustacea, Vol. 8, Environmental adaptations. Academic Press, New York, p. $1-42$

Vos, J., Bernaerts, F., Gabriels, I., Decleir, W. (1979). Aerobic and anaerobic respiration of adults Artemia salina L., acclimated to different oxygen concentrations. Comp. Biochem. Physiol. 62: 545-548

Widdows, J. (1973). The effects of temperature on the metabolism and activity of Mytilus edulis. Neth. J. Sea Res. 7. $387-398$

Zainal, K. A. Y (1990). Aspects of the biology of the squat lobster, Munida rugosa (Fabricius, 1775). Ph. D. thesis, University of Glasgow

Zar, J. H. (1984). Biostatistical analysis, 2nd edn. Prentice-Hall Inc., Englewood Cliffs, New Jersey

Manuscript first received: January 29, 1991

Revised version accepted: June 27, 1991 